\title{
ReMOÇÃo de ETANOL E BENZENo EM REATOR ANAERÓBIO HORIZONTAL DE LEITO FIXO NA PRESENÇA DE SULFATO
}

\section{ETHANOL AND BENZENE REMOVAL IN A HORIZONTAL-FLOW ANAEROBIC IMMOBILIZED BIOMASS REACTOR IN THE PRESENCE OF SULFATE}

\section{EDUardo Bosco Mattos Cattony}

Biólogo (UFSCar). Doutor em Engenharia Civil - Departamento de Hidráulica e Saneamento (EESC/USP)

\author{
ROGERS RIBEIRO \\ Engenheiro Químico (UNICAMP). Doutor em Engenharia Civil - Departamento de Hidráulica e \\ Saneamento (EESC/USP)
}

\section{MARCELO ZAIAT}

Engenheiro Químico (UFSCar). Professor Doutor do Departamento de Hidráulica e Saneamento (EESC/USP)

\section{EUGENNIO FORESTI}

Engenheiro Civil (EESC/USP). Professor Doutor do Departamento de Hidráulica e Saneamento (EESC/USP)

\author{
MARIA BERNADETE AMÂNCIO VARESCHE
}

Bióloga (UNESP/Botucatu). Professora Doutora do Departamento de Hidráulica e Saneamento (EESC/USP)

Recebido: 03/05/06 Aceito: 15/03/07

\section{RESUMO}

Reator anaeróbio horizontal de leito fixo (RAHLF), preenchido com espumas de poliuretano, foi usado para tratar benzeno em solução etanólica, sob condições sulfetogênicas. Benzeno foi adicionado em concentração inicial de 2,0 mg.1 ${ }^{-1}$, seguido de aumentos que variaram até $10 \mathrm{mg} . \mathrm{l}^{-1}$. $\mathrm{O}$ etanol foi adicionado em concentrações de $170 \mathrm{mg} \cdot \mathrm{l}^{-1}$ a $980 \mathrm{mg} \cdot \mathrm{l}^{-1}$. Soluções de sulfato ferroso e sulfato de sódio foram usadas, nas concentrações

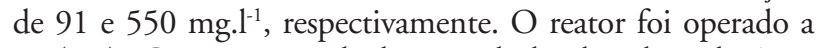
$30( \pm 2){ }^{\circ} \mathrm{C}$ com tempo de detenção hidráulica de $12 \mathrm{~h}$. A remoção da matéria orgânica foi próxima a $90 \%$ com taxa máxima de degradação de benzeno de $0,07 \mathrm{mg}_{\text {benzeno }} \cdot \mathrm{mg}^{-1} \mathrm{SSV} \cdot \mathrm{d}^{-1}$. O presente trabalho corrobora os dados obtidos por Cattony et al (2005), na medida em que torna mais consistente a proposta do uso de unidades compactas de RAHLF, para a biorremediação in situ de compostos aromáticos.

PALAVRAS-CHAVE: Benzeno, etanol, reator anaeróbio, biofilme, redução de sulfato e PCR/DGGE.

\section{INTRODUÇÃO}

Os campos da engenharia sanitária e ambiental, aliados a biotecnologia, têm evoluído rapidamente no desenvolvimento de métodos para o tratamento de águas residuárias. Isso ocorre principalmente em razão das exigências cada vez maiores dos órgãos públicos de

\section{ABSTRACT}

In this study it is reported the operation of a horizontalflow anaerobic immobilized biomass (HAIB) reactor under sulfate-reducing condition which was also exposed to different amounts of ethanol and benzene. The HAIB reactor comprised of an immobilized biomass on polyurethane foam and ferrous and sodium sulfate solutions were used (91 and $550 \mathrm{mg} . \mathrm{l}^{-1}$, respectively), to promote a sulfate-reducing environment. Benzene was added at an initial concentration of $2.0 \mathrm{mg} . \mathrm{t}^{-1}$ followed by an increased to 9 e $10 \mathrm{mg} . \mathrm{l}^{-1}$, respectively. Ethanol was added at an initial concentration of $170 \mathrm{mg} . \mathrm{t}^{-1}$ followed by an increased range of $960 \mathrm{mg} . \mathrm{l}^{-1}$. The reactor was operated at $30( \pm 2)^{\circ} \mathrm{C}$ with hydraulic detention time of $12 \mathrm{~h}$. Organic matter removal efficiency of $90 \%$ with a maximum benzene degradation rate of $0.07 \mathrm{mg}$ benzene. $m g_{\text {VSS. }} \cdot \mathrm{d}^{-1}$. Thus, this work corroborate the data obtained for Cattony et al (2005) and also demonstrate that compact units of HAIB reactors, under sulfate reducing conditions, are a potential alternative for in situ aromatic compounds bioremediation.

KEYWORDS: Benzene, ethanol, anaerobic reactor, biofilm, sulfate reduction and PCR/DGGE.

controle do ambiente, como resposta ao interesse da saúde pública, das crescentes condições adversas causadas pelas descargas de águas residuárias e de uma maior cobrança da sociedade na defesa do ambiente.

Inserido neste contexto, a Companhia de Tecnologia de Saneamento Ambiental (CETESB) publicou (em Maio de 2002) um relatório no qual havia a afirmação de que aproximadamente 80\% das contaminações de águas subterrâneas no estado de São Paulo-Brasil eram ocasionadas por vazamentos de postos de combustível. Os maiores problemas de contaminação são atribuídos aos hidrocarbonetos monoaromáticos denominados BTEX (benzeno, tolue- 
no, etilbenzeno e xilenos) que são os constituintes da gasolina mais solúveis e com maior potencial de migração nas águas subterrâneas (Franzmann et al, 2002). Porém, como a gasolina brasileira é uma mistura de aproximadamente $76 \%$ de gasolina e $24 \%$ de etanol, o álcool também representaria problema de contaminação, ainda mais, se levado em conta, o seu potencial em aumentar a solubilidade de compostos orgânicos aromáticos (Corseuil et al, 2004).

Tais constatações motivaram o grupo do Laboratório de Processos Biológicos, da Escola de Engenharia da USP de São Carlos, a desenvolver um sistema de baixo custo e alta eficiência para o tratamento biológico das águas subterrâneas contaminadas por vazamentos de gasolina.

Alguns trabalhos de pesquisa já foram realizados dentro deste grupo; tais como, "Anaerobic Degradation of BTEX in a Packed-Bed reactor" (De Nardi et al, 2002), "Ethanol and toluene removal in a horizontal-flow anaerobic immobilized biomass reactor in the presence of sulfate" (Cattony et al, 2005) e "Anaerobic Packed-Bed Reactor for Bioremediation of Gasoline-Contaminated Aquifers" (De Nardi et al, 2005). Sendo assim, o presente trabalho visou dar continuidade a mesma linha de pesquisa realizada por Cattony et al (2005), ou seja, o RAHLF como sistema de baixo custo e alta eficiência para o tratamento biológico de águas subterrâneas contaminadas por compostos orgânicos aromáticos. No presente trabalho foi dado ênfase a remoção de benzeno na presença de sulfato.

\section{MATERIAL E MÉTODOS}

O reator anaeróbio horizontal de leito fixo (RAHLF) foi construído em vidro de boro-silicato, com $100 \mathrm{~cm}$ de comprimento e $5 \mathrm{~cm}$ de diâmetro, perfazendo 2,0 L de capacidade (Figura 1). O RAHLF foi preenchido com matrizes de espuma contendo lodo imobilizado proveniente de reator UASB. O lodo foi macerado em liquidificador com meio basal Zinder (Zinder et al, 1984) e colocado em contato com espumas de poliuretano por período de aproximadamente 24 horas. Após este período de imobilização da biomassa, as espumas foram transferidas para o interior dos reatores (Zaiat, 1996).

\section{Inóculo}

O reator foi inoculado com lodo proveniente de reator UASB (reator anaeróbio de fluxo ascendente e manta de lodo) usado no tratamento de águas residuárias provenientes de abatedouro de aves.

\section{Material suporte para crescimento microbiano}

Foram usadas espumas de poliuretano (densidade aparente de $23 \mathrm{~kg} . \mathrm{m}^{-3}$ ) cortadas em cubos de $0,5 \mathrm{~cm}$ de aresta.

\section{Condições operacionais}

A Figura 2 mostra o diagrama das fases $1,2,3,4$ e 5 , onde estão descritas as composiçōes do meio Zinder usadas em cada fase.

O reator foi mantido a temperatura controlada de, aproximadamente, $30 \pm 2{ }^{\circ} \mathrm{C}$, com tempo de detenção hidráulica (TDH) de $12 \pm 0,5 \mathrm{~h}$ em todas as fases. O reservatório afluente ao reator, foi submetido a atmosfera de nitrogênio/dióxido de carbono (70/30\%) por 15 minutos, antes de ser conectado ao reator, a fim de se manter as condiçôes de anaerobiose do sistema.
A bolsa de gás acoplada ao frasco de alimentação teve como função manter a atmosfera do frasco em condições de anaerobiose.

Após período inicial de enriquecimento do biofilme, o reator foi usado para o ensaio com benzeno. Como substrato para as bactérias, foi utilizado o meio basal descrito por Zinder et al (1984). A solução de vitaminas utilizada foi a descrita por Touzel \& Albagnac (1983), acrescida de ácido 4-aminobenzóico (4 mg.l $\left.{ }^{1-1}\right)$. Segundo Widdel \& Bak (1992), este ácido é necessário ao melhor desenvolvimento de BRS. A princípio foi utilizada relação $\mathrm{DQO} / \mathrm{SO}_{4}^{2-i g u a l}$ a 2:1 na alimentação do reator. Todavia, com o decorrer do experimento está relação não foi mais respeitada.

$\mathrm{Na}$ fase 1, de enriquecimento do biofilme, o reator foi alimentado com lactato de sódio e etanol (99\%), nas concentrações de 750 mg..$^{-1}$ e 170 mg..$^{-1}$, respectivamente. Nessa fase, foram adicionados sulfato ferroso e sulfato de sódio nas concentrações de $91 \mathrm{mg} . \mathrm{l}^{-1}$ e $550 \mathrm{mg} . \mathrm{l}^{-1}$, respectivamente. Após a adição de benzeno, lactato de sódio não foi mais usado e as concentrações de etanol e de sulfato de sódio foram elevadas para $490 \mathrm{mg} \cdot \mathrm{l}^{-1} \mathrm{e}$ $695 \mathrm{mg} .1^{-1}$, respectivamente. A concentração de sulfato ferroso não foi alterada em nenhuma fase dos experimentos. Sendo assim, o conteúdo total de íon sulfato no substrato afluente foi de $400 \mathrm{mg} . \mathrm{l}^{-1}$ na fase 1 e de $500 \mathrm{mg} . \mathrm{l}^{-1}$ nas fases subseqüentes. A concentração final de sulfato foi definida experimentalmente, após, a estabilização do sistema; ou seja, para concentraçôes de sulfato de sódio superiores a $500 \mathrm{mg} . \mathrm{l}^{-1}$ no substrato afluente, sempre foram observadas concentraçôes residuais de sulfato no efluente. Desse modo, o conteúdo equivalente aos valores residuais foi, então, subtraído do meio nutritivo.

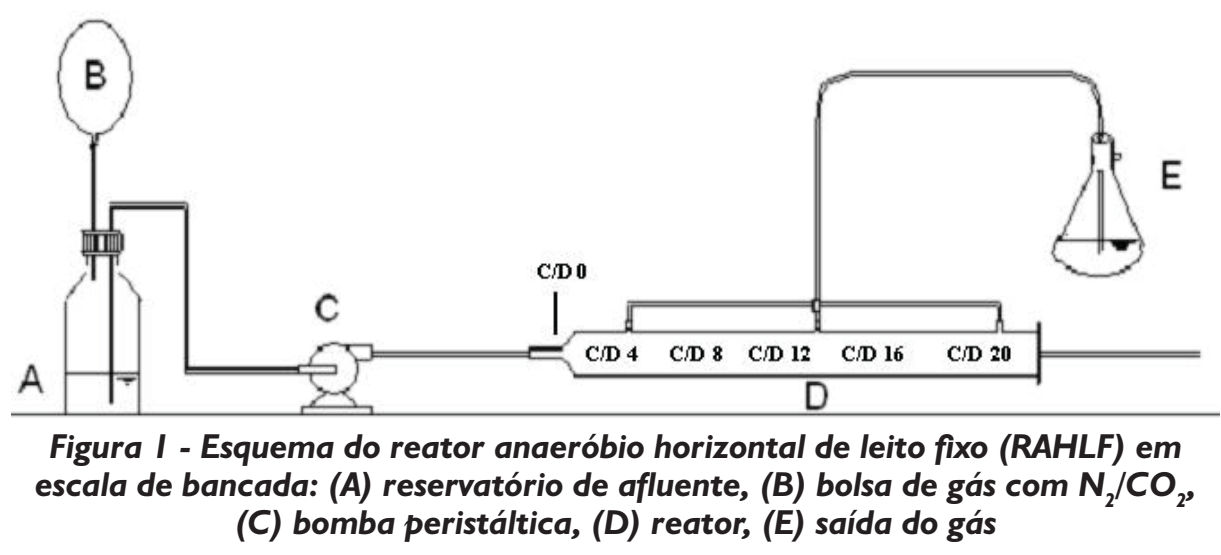




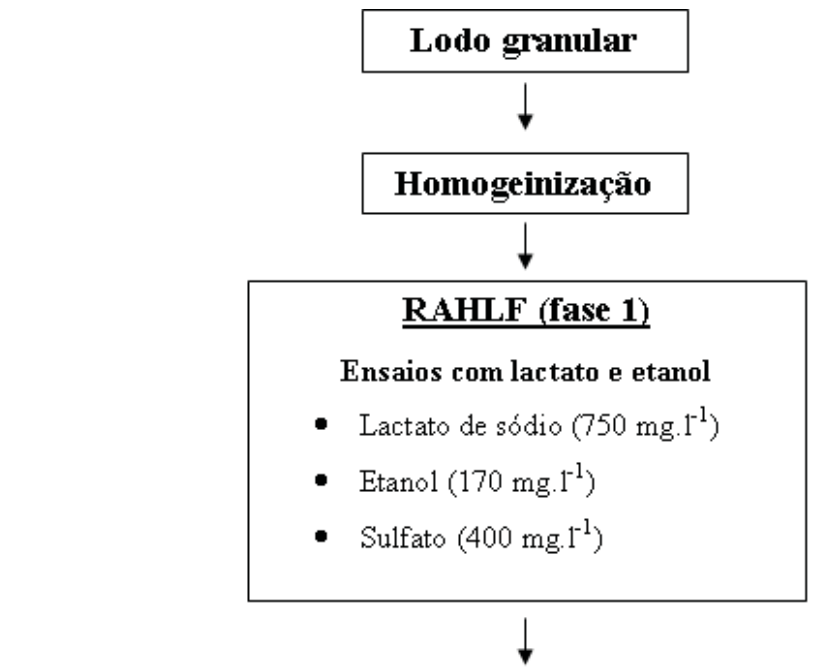

\section{RAHLF (fases 2, 3, 4 e 5)}

Ensaios com aumento das concentrações de etanol e benzeno

- Benzeno a 2, 5, 7 e $10 \mathrm{mg} \cdot \mathrm{l}^{-1}$

- Concentrações de etanol de $490 \mathrm{mg} \cdot 1^{-1}$ nas fases 2 e 3 , e $980 \mathrm{mg} \cdot 1^{-1}$ nas fases 4 e 5

- Concentração final de sulfato de $500 \mathrm{mg} \cdot 1^{-1}$

Figura 2 - Diagrama das fases operacionais I, 2, 3, 4 e 5 em RAHLF. Na figura a concentração de sulfato refere-se ao íon e não a solução de sulfato de sódio

O etanol foi utilizado como substrato principal, nas fases 2, 3, 4 e 5, por sua capacidade de aumentar a solubilidade de benzeno no meio e, conseqüentemente, favorecer a disponibilidade do mesmo. Sendo assim, benzeno foi adicionado em volume calculado de etanol (99\%) antes de ser misturado ao substrato sintético. $\mathrm{Na}$ fase de enriquecimento (fase 1), volume específico de etanol (99\%) foi adicionado diretamente ao meio para a obtenção da concentração final de 170 mg. $\mathrm{l}^{-1}$.

Nas fases 2 e 3, a concentração de etanol foi elevada de 170 para $490 \mathrm{mg} \cdot \mathrm{l}^{-1}$. Nas fases 4 e 5 , houve a necessidade do aumento da concentração de etanol para $980 \mathrm{mg} \cdot \mathrm{l}^{-1}$ possibilitando, deste modo, a solubilização completa do composto aromático no meio.

$\mathrm{O}$ aumento nas concentrações de benzeno só ocorreu depois da estabilização do reator verificada através dos valores obtidos para conteúdo de matéria orgânica (expressa em DQO), conteúdo de sulfato, de sólidos suspensos voláteis (SSV), de ácidos e alcalinidade gerados (método volumétrico) na entrada e saída do reator. Depois de verificada a estabilização do reator, foram realizadas amostragens ao longo de todo o leito do reator. Nesta fase, foram realizadas análises do conteúdo de matéria orgânica, conteúdo de sulfato, sólidos suspensos voláteis, de ácidos e alcalinidade, ácidos orgânicos e compostos aromáticos por cromatografia gasosa. Somente, após estas análises as concentrações dos compostos aromáticos foram aumentadas configurando nova fase operacional.

\section{Amostragem}

As amostras estudadas foram retiradas do afluente, efluente e ao longo do reator. Os pontos de amostragem correspondem a relação $\mathrm{C} / \mathrm{D}$ (comprimento/diâmetro) de $0,4,8,12,16$ e 20 (Figura 1). O zero representa o afluente.

\section{Análises físico-químicas}

As análises de demanda química de oxigênio (DQO), sólidos suspensos voláteis (SSV) e sulfato foram realizadas de acordo com métodos descritos no Standard Methods for Examination of Water and Wastewater (1998). Somente as amostras usadas para as análises de DQO e sulfato foram filtradas em membranas com diâmetro de poro de $0,45 \mu \mathrm{m}$.

As análises de SSV da biomassa final foram realizadas com dez espumas de poliuretano retiradas do trecho inicial e final do leito do reator na fase de enriquecimento e ao final da fase

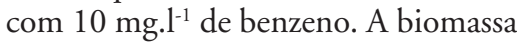
aderida foi extraída através de agitação manual em frascos de antibiótico com pérolas de vidro e água destilada (2 g de pérolas/10 $\mathrm{ml}$ de água). Os frascos foram agitados durante 20 minutos em ângulo de $45^{\circ}$. Posteriormente, a biomassa livre foi transferida para cápsulas apropriadas para a análise de SSV.

As análises volumétricas de ácidos e alcalinidade seguiram os protocolos propostos por Dilallo \& Albertson (1961) e modificada por Ripley et al (1986), respectivamente.

\section{Análises cromatográficas}

A composição do biogás foi analisada na atmosfera do reator através de cromatografia gasosa utilizando cromatógrafo Gow Mac, serie 150, com detector de condutividade térmica. Foi utilizada coluna Porapak Q, temperatura de injeção de $50^{\circ} \mathrm{C}$, volume de injeção de $0,5 \mathrm{~mL}$ e fluxo do gás de arraste (hidrogênio) de $60 \mathrm{~mL} \cdot \mathrm{min}^{-1}$.

As análises de ácido acético e propiônico foram realizadas por cromatografia gasosa (GC-FID HP 6890, HP-1 coluna $100 \%$ bi-methylpolissiloxano) segundo Moraes et al, 2000. As análises de benzeno foram realizadas por cromatografia gasosa (GC-FID HP 6890, HP-1 coluna 100\% dimetilpolissiloxano) segundo De Nardi et al, 2002.

\section{Modelo cinético}

Foi proposto modelo cinético a partir de reações paralelas em série de primeira e segunda ordem irreversíveis com dois produtos metabólicos intermediários para a remoção de benzeno. As constantes cinéticas do processo descritas na Figura 3 foram estimadas através de otimização algorítmica baseada no método Runge-Kutta (Microsoft Excel 2000 - Solver).

O balanço de massa realizado para cada substrato e para os produtos intermediários, considerando o reator 


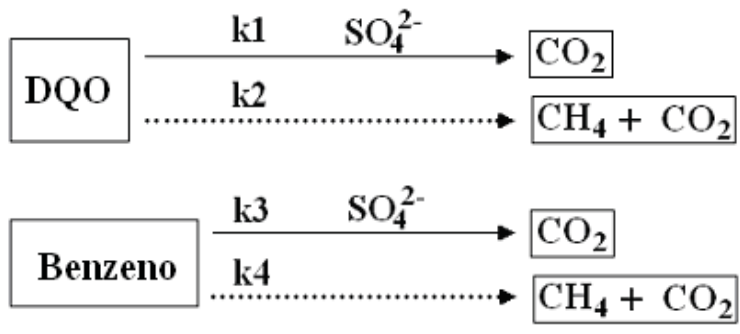

Figura 3 - Diagrama do modelo cinético proposto

como perfeito plug-flow (De Nardi et al, 1999), resultaram nos seguintes sistemas de equações diferenciais não lineares:

Balanço de massa para DQO;

$$
\begin{aligned}
& -\frac{\mathrm{v}_{\mathrm{S}}}{\mathrm{D}} \cdot \frac{\mathrm{dC}_{\mathrm{DQO}}}{\mathrm{d}\left(\frac{\mathrm{C}}{\mathrm{D}}\right)}=\mathrm{k}_{1} \cdot\left(\mathrm{C}_{\mathrm{DQO}}-\mathrm{C}_{\mathrm{DQO}}-\mathrm{R}\right) . \\
& \mathrm{C}_{\mathrm{SO}_{4}^{2}}+\mathrm{k}_{2} \cdot\left(\mathrm{C}_{\mathrm{DQO}}-\mathrm{C}_{\mathrm{DQO}-\mathrm{R}}\right)
\end{aligned}
$$

Balanço de massa para Benzeno;

$$
\begin{aligned}
& -\frac{\mathrm{v}_{\mathrm{s}}}{\mathrm{DD}} \frac{\mathrm{dC}_{\text {benzeno }}}{\mathrm{d}\left(\frac{\mathrm{C}}{\mathrm{D}}\right)}=\mathrm{k}_{3} \cdot \mathrm{C}_{\text {benzeno }} . \\
& \mathrm{C}_{\mathrm{SO}_{4}^{2}}-+\mathrm{k}_{4} \cdot \mathrm{C}_{\text {benzeno }}
\end{aligned}
$$

Balanço de massa para sulfato; $-\frac{\mathrm{V}_{\mathrm{S}}}{\mathrm{D}} \frac{\mathrm{dC}_{\mathrm{SO}_{4}^{2-}}}{\mathrm{d}\left(\frac{\mathrm{C}}{\mathrm{D}}\right)}=\left[\mathrm{k}_{1} .\left(\mathrm{C}_{\mathrm{DQO}}-\right.\right.$

$$
\left.\left.-\mathrm{C}_{\mathrm{DQO}-\mathrm{R}}\right)+\mathrm{k}_{3} \cdot \mathrm{C}_{\text {tolueno }}\right] \cdot \mathrm{C}_{\mathrm{DO}_{4}^{2-}}
$$

As equações (1) a (3) estão relacionadas a: (1) degradação de matéria orgânica (DQO), (2) remoção de benzeno, (3) consumo de sulfato. O significado de cada parâmetro é dado a seguir: $\mathrm{D}$ é o diâmetro do reator; $\mathrm{C}$ é o comprimento; $\mathrm{v}_{\mathrm{S}}$ é a velocidade superficial; $\mathrm{C}_{\mathrm{DQO}}$ é a concentração de matéria orgânica $\left(\mathrm{mg}_{\mathrm{DQO}} .^{-1}\right)$; Cbenzeno é a concentração de benzeno $\left(\mathrm{mg}_{\text {benzeno }} \mathrm{l}^{-1}\right)$; $\mathrm{CSO}_{4}^{2-}$ é a concentração de sulfato $\left(\mathrm{mg}_{\text {sulfato }} . \mathrm{l}^{-1}\right) ; \mathrm{C}_{\text {DQO_R }}$ é a concentração de matéria orgânica residual $\left(\mathrm{mg}_{\mathrm{DQO} \_\mathrm{R}} \cdot \mathrm{l}^{-1}\right)$; k1 e k3 (mg.. ${ }^{-1}$ sulfato.h $\left.\mathrm{h}^{-1}\right)$ são os coeficientes cinéticos aparentes de segunda-ordem, e k2 e k4 $\left(\mathrm{h}^{-1}\right)$ são os coeficientes cinéticos aparentes de primeira-ordem. A adsorção do composto aromático não foi considerada no modelo matemático devido ao fato de não ter sido considerada etapa limitante nas taxas de remoção.

\section{Exames microscópicos}

O exame microbiológico do lodo enriquecido e biofilme foi realizado em microscópio Leica DM LB, acoplado a câmara Leica DC 200 e software ImagePro plus (versão 4.5.0.19).
As células crescidas na espuma de poliuretano foram observadas, também através de microscopia eletrônica de varredura (MEV), conforme método descrito por Nation (1983).

\section{Análises de biologia molecular}

No presente trabalho, a partir do DNA extraído da biomassa aderida as espumas de poliuretano, foram obtidos fragmentos de DNAr 16S, utilizando-se a técnica do PCR com primers homólogos a regiōes conservadas do gene RNAr 16S. Os primers usados foram os seguintes: 968F-GC e 1392R específicos para o Domínio Bacteria; GM5F-GC e 907R específicos para BRS, 1100F-GC e 1400R que amplificam o DNA $16 S$ do Domínio Archaea. Como o inóculo utilizado no reator apresentava comunidades mistas de microrganismos, foram realizadas três abordagens de estudo: (1) análise da comunidade bacteriana, (2) análise da comunidade de BRS e (3) análise da comunidade de arquéias (Tabela 1).

As amplificações foram realizadas com o uso de termociclador "Gene Amp PCR System 2400" (Perkin-Elmer Cetus, Norwalk, Conn.). Para as amplificações específicas de fragmentos de DNAr 16S para o grupo das BRS, para Bacteria e para Archaea, foi utilizada mistura de reação (volume final de $50 \mu \mathrm{l}$ ) descrita a seguir: $0,8 \mu \mathrm{l}$ de Taq DNA polimerase (5 U/ $\mu \mathrm{l}), 10 \mu \mathrm{l}$ de tampão da Taq (1x)

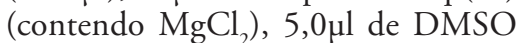
(5\%), 0,8 $\mu \mathrm{l}$ de dNTP's $(0,2 \mathrm{mM})$, $2 \mu \mathrm{l}$ de F968 $(0,4 \mu \mathrm{M}), 2 \mu \mathrm{l}$ de R1392 $(0,4 \mu \mathrm{M}), 2 \mu \mathrm{l}$ de $1100 \mathrm{~F}(0,4 \mu \mathrm{M})$ e $2 \mu \mathrm{l}$ de $1400 \mathrm{R}(0,4 \mu \mathrm{M})$. A amplificação para BRS e Bacteria ocorreu seguida de 35 ciclos variando-se a temperatura entre $92^{\circ} \mathrm{C}$ (por 30 segundos), $57^{\circ} \mathrm{C}$ (por 1 minuto) e $72^{\circ} \mathrm{C}$ (por 45 segundos); 1 ciclo a temperatura de $72^{\circ} \mathrm{C}$ (por 5 minutos) e, finalmente, resfriamento à $4^{\circ} \mathrm{C}$. A amplificação para Archaea ocorreu seguida de 30 ciclos variando-se a temperatura entre $94^{\circ} \mathrm{C}$ (por 30 segun- dos), $55^{\circ} \mathrm{C}$ (por 30 segundos) e $72^{\circ} \mathrm{C}$ (por 1 minuto e 30 segundos); 1 ciclo a temperatura de $72^{\circ} \mathrm{C}$ (por 3 minutos) e finalmente resfriamento à $4^{\circ} \mathrm{C}$.

O sistema de DGGE utilizado foi o "DCode ${ }^{\mathrm{TM}}$ - Universal Mutation Detection System" (Bio-Rad, Inc., Hercules, Califórnia) e, utilizado, exatamente, como descrito pelos fabricantes no manual de instruçōes. Os géis paralelos foram feitos variando-se a concentração de desnaturante (uréia) de 30 a $70 \%$. Os géis polimerizaram pela adição de $150 \mu \mathrm{l}$ de persulfato de amônio $10 \%$ e $14 \mu$ lde TEMED (para concentração final de $0,09 \%$ ). As eletroforeses ocorreram na voltagem constante de $50 \mathrm{~V}$ e temperatura de $60^{\circ} \mathrm{C}$ por 14 horas. As alíquotas de PCR adicionadas no gel foram de $24 \mu \mathrm{l}$. Os géis foram corados com $10 \mathrm{ml}$ de solução de coloração (TAE $1 \mathrm{x}$ contendo $1 \mu \mathrm{g} / \mathrm{ml}$ de Brometo de Etídeo). Finalmente, os géis foram fotografados em câmara escura "Eagle Yey II" (Stratagene) e processados com o software "Eaglesight" (Stratagene - versão 3.22).

\section{RESULTADOS E DISCUSSÃO}

O ensaio contínuo em RAHLF foi iniciado com alimentação baseada no meio Zinder acrescido de lactato de sódio, etanol e ácido 4-aminobenzóico. Sob tais condições o reator foi alimentado por período de, aproximadamente, 15 dias, até a completa estabilização do sistema, a qual foi verificada através das análises físico-químicas. Após esta fase de enriquecimento (fase 1), foram iniciados ensaios com as concentraçốes crescentes de benzeno, 2, 5, 7 e 10 mg.l $\mathrm{l}^{-1}$ (fases 2, 3,4 e 5 , respectivamente).

A concentração de matéria orgânica expressa como DQO, a carga orgânica volumétrica e a concentração de sulfato, afluente e efluente do reator, em todos os ensaios com benzeno, estão mostrados na Figura 4.

$\mathrm{Na}$ fase 1 , a DQO inicial afluente foi de, aproximadamente, $1000 \pm 7 \mathrm{mg} . \mathrm{l}^{-1}$, diminuindo para cerca de $130 \pm 6 \mathrm{mg} . \mathrm{l}^{-1}$ (eficiência de remoçáo de aproximadamente $87 \%$ ) no efluente. Foram necessários 15 dias, aproximadamente, para que os valores de DQO se estabilizassem, sendo que o maior consumo da matéria orgânica, expressa em DQO, ocorreu logo no primeiro trecho do reator, correspondendo aos pontos de amostragem $\mathrm{C} / \mathrm{D}$ 4 e C/D 8. No restante do reator, não 
Tabela I - Primers usados nos experimentos com PCR

\begin{tabular}{|c|c|c|c|}
\hline Primers $^{a}$ & DNAr $16 S$ alvo & Seqüência $\left(5^{\prime} \rightarrow 3^{\prime}\right)$ & Referência \\
\hline 968F-GC & Bacteria & GC-AACGCGAAGAACCTTAC & \multirow{2}{*}{$\begin{array}{c}\text { Nielsen et al } \\
(1999)\end{array}$} \\
\hline 1392R & Bacteria & ACGGGCGGTGTGTAC & \\
\hline 1100F-GC & Archaea & GC-AACCGTCGACAGTCAGGYAACGAGCGAG & \multirow{2}{*}{$\begin{array}{l}\text { Kudo et al } \\
\text { (1997) }\end{array}$} \\
\hline 1400R & Archaea & CGGCGAATTCGTGCAAGGAGCAGGGAC & \\
\hline GM5F-GC & BRS & CCTACGGGAGGCAGCAG & $\begin{array}{l}\text { Nakagawa } \\
\text { et al (2002) }\end{array}$ \\
\hline $907 R$ & Universal & CCGTCAATTCCTTTRAGTTT & $\begin{array}{l}\text { Muyzer et al } \\
(1995)\end{array}$ \\
\hline GC. & & CGCCCGGGGCGCGCCCCGGGCGGGGCGGGGGCACGGGGGG & $\begin{array}{c}\text { Muyzer et al } \\
(1996)\end{array}$ \\
\hline
\end{tabular}

${ }^{a}$ F, forward primers; R, Reverse primers; GC., seqüência rica em G+C anexada ao final 5' da molécula de DNA.

houve alteração significativa da DQO (Figura 4A). Nas fases de alimentação com benzeno a eficiência na remoção de matéria orgânica aumentou, sensivelmente, com exceção da fase 4 onde houve incremento na concentração de etanol de 460 para $960 \mathrm{mg} . \mathrm{l}^{-1}$.

Após a introdução de $5 \mathrm{mg} .1^{-1}$ benzeno na fase 2 , a eficiência de remoção da matéria orgânica aumentou para $92 \%$, ou seja, $1000 \pm 4 \mathrm{mg} . \mathrm{l}^{-1}$ foram reduzidos a $80 \pm 3 \mathrm{mg} . \mathrm{l}^{-1}$ no efluente. Esta eficiência se manteve inalterada na fase 3, diminuiu para $90 \%$ na fase 4 e melhorou até o valor de $97 \%$ na fase 5 . Estes valores indicaram que as concentrações de 2, 5, 7 e $10 \mathrm{mg} . \mathrm{l}^{-1} \mathrm{de}$ benzeno estudadas não foram prejudiciais ao equilíbrio do sistema. O maior consumo de matéria orgânica, em todos os ensaios, ocorreu sempre no primeiro trecho do reator, correspondendo aos pontos de amostragem C/D 4 a 8. Nos demais pontos de amostragem ao longo do reator, constatou-se a presença de DQO residual, cujo valor, praticamente, não se alterou (Figura 4A).

Vários trabalhos já demonstraram a importância do sulfato, em sítios contaminados com compostos orgânicos aromáticos, uma vez que este aceptor final de elétrons possibilita o desenvolvimento de bactérias redutoras de sulfato (BRS) (Boopathy et al, 1998; Kolmert et al, 2000; Franzmann et al, 2002; Da Silva et al, 2005). Confirmando a tendência dos dados obtidos in situ, pelos autores anteriormente citados, o biofilme sulfetogênico formado no RAHLF também se mostrou capaz de remover tolueno (Cattony et al, 2005). No presente trabalho, a remoção do sulfato, na fase 1, apresentou o mesmo comportamento da matéria orgânica e sugeriu a presença de BRS (Figura 4B).
Elevada eficiência de remoção, próxima a $100 \%$, foi verificada no primeiro trecho do reator (C/D 4 a 8), após 15 dias de enriquecimento.

$\mathrm{O}$ pH efluente próximo a 7,9 $( \pm 0,1)$ na fase de enriquecimento (Figura 4C), mostrou-se ligeiramente mais alcalino, em relação ao afluente de 7,6 $( \pm 0,1)$. Esta leve tendência de alcalinização foi comprovada, também, pelas análises volumétricas de alcalinidade (Figura 4D), correspondendo a $131 \pm 8 \mathrm{mg} . \mathrm{l}^{-1}$ e $195 \pm 5 \mathrm{mg} . \mathrm{l}^{-1}$, respectivamente. Esses valores, também, foram relacionados com a produção de bases de sais de ácidos inorgânicos fracos (como, por exemplo, bicarbonato), de sais de ácidos voláteis (acético e propiônico na fase 1) e pela formação de íons $\mathrm{OH}^{-}$devido a hidrólise da água promovida pelos íons HS- e $\mathrm{S}^{2-}$.

Esta capacidade de alcalinização do reator se mostrou eficiente em todos os ensaios com benzeno. Mesmo com $\mathrm{pH}$ afluente tendo seu valor diminuído sensivelmente em todos os diferentes ensaios, principalmente na fase 5 , com valor em torno de 7,4 $( \pm 0,1)$, o pH efluente se manteve estável próximo ao valor de 7,7 $( \pm 0,1)$.

Após a adição de benzeno, as concentrações de etanol adicionadas ao meio foram elevadas com a intenção de aumentar a solubilidade do composto aromático. $\mathrm{O}$ valor de $170 \mathrm{mg} \cdot \mathrm{l}^{-1}$, na fase 1 , foi elevado para $490 \mathrm{mg} \cdot 1^{-1}$ nas fases 2 e 3 . Nas fases 4 e 5, foi necessária concentração de etanol afluente de $960 \mathrm{mg} \cdot \mathrm{l}^{-1}$. Estes aumentos na concentração de etanol, que é um ácido fraco, foram também responsáveis pela diminuição nos valores de $\mathrm{pH}$ afluente.

A análise volumétrica de ácidos (Figura 4E) apresentou valores contrastantes na fase 1 . Devido a grande diferença entre as concentrações de etanol no afluente da fase 1 em relação as fases 4 e 5 , iguais a $170 \mathrm{mg} \cdot \mathrm{l}^{-1} \mathrm{e}$ $960 \mathrm{mg} . \mathrm{l}^{-1}$, respectivamente, o acúmulo de ácidos orgânicos gerado pela oxidação do etanol produzindo, principalmente, ácido acético, foi maior nas últimas duas condiçôes. As fases 2 e 3 apresentaram concentração intermediária de etanol e, portanto, valores intermediários de acúmulo de ácido. Como já observado por Cattony et al (2005), as diferenças entre os valores obtidos nas análises de DQO e de ácidos nas amostras de efluente refletem as limitações da abordagem proposta por Dilallo \& Albertson (1961). É possível que as concentrações residuais de $\mathrm{S}^{2-}$ tenham interferido na análise. $\mathrm{O} \mathrm{S}^{2-}$ pode ter provocado acréscimo nos valores de ácidos devido a formação de $\mathrm{Na}_{2} \mathrm{~S}$, o que explicaria estas discrepâncias.

Os sólidos suspensos voláteis (SSV) afluente (Figura 4F) apresentaram valores próximos a $80 \pm 3 \mathrm{mg} . \mathrm{l}^{-1} \mathrm{e}$ no efluente próximos a $30 \pm 4 \mathrm{mg} \cdot \mathrm{l}^{-1}$, em todas as condiçôes.

Foi observada, também, a detecção de metano no biogás, tendo sua porcentagem variado entre 10 e $55 \%$ em todas as fases de operação do reator.

Quanto ao benzeno, observou-se sua remoção antes do segundo ponto de amostragem do reator (C/D 8) em todos as fases, remanescendo apenas a concentração residual de aproximadamente $0,2 \pm 0,1 \mathrm{mg} .1^{-1}$ nas fases 2 e 3 e $0,8 \pm 0,1 \mathrm{mg} . \mathrm{l}^{-1}$ nas fases 4 e 5 . Sendo assim, o consumo do benzeno teve o mesmo comportamento observado para sulfato e matéria orgânica (expressa em DQO).

Burland \& Edwards (1999) sugeriram a seguinte reação (4) para a oxidação de benzeno em condiçóes sulfetogênicas: 

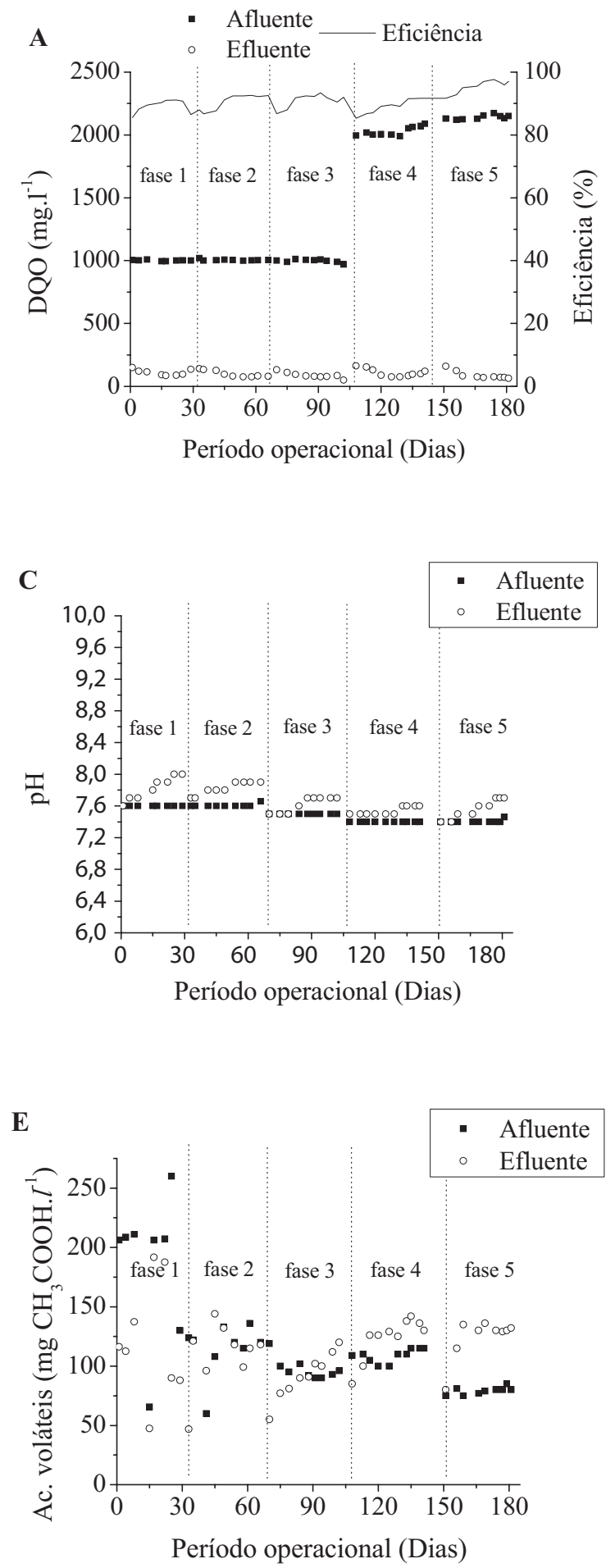
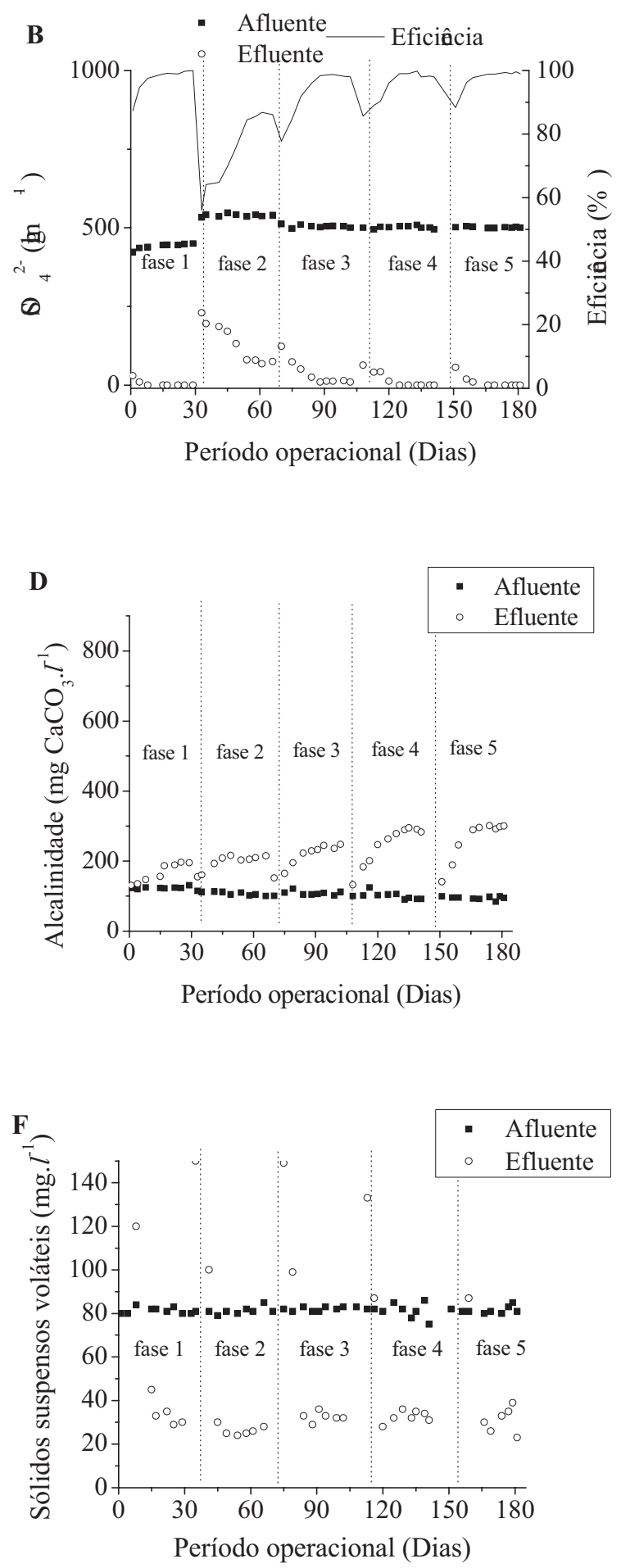

Figura 4 - Variação temporal da matéria orgânica (DQO) (A), sulfato (B), $\mathrm{pH}$ (C), alcalinidade

(D), ácidos (E) e sólidos suspensos voláteis (SSV) (F), nas diferentes fases operacionais do RAHLF alimentado com benzeno

$\mathrm{C}_{6} \mathrm{H}_{6}+3,75 \mathrm{SO}_{4}^{2-}+3 \mathrm{H}_{2} \mathrm{O} \rightarrow 1,875 \mathrm{H}_{2} \mathrm{~S}+$

$1,87 \mathrm{HS}^{-}+6 \mathrm{HCO}_{3}^{-}+0,375 \mathrm{H}^{+}$

Considerando-se que as células estivessem oxidando benzeno através da redução de sulfato, em todas as diferentes concentrações, no total teriam sido consumidos de 30 a 170 mg.l ${ }^{-1} \mathrm{de}$ sulfato. O restante do sulfato consu- mido, aproximadamente, $330 \mathrm{mg} . \mathrm{l}^{-1}$, teriam sido, usados na oxidação de toda a matéria orgânica (ácido acético e, principalmente, etanol) distribuída no leito do reator.

A Tabela 2 e Figura 5 apresentam as variações espaciais obtidas para cada fase operacional e os resultados do mo- delo cinético proposto (reaçōes paralelas em série irreversíveis com dois produtos intermediários). De acordo com o modelo, a análise dos valores de $\mathrm{k}_{1} \mathrm{e}$ $\mathrm{k}_{2}$ revelaram que as taxas de consumo de matéria orgânica, pela sulfetogênese ou pelo metabolismo fermentativo, foram similares quando submetidas a 
concentrações de sulfato próximas a $300 \mathrm{mg} \cdot \mathrm{l}^{-1}$, desde que $\mathrm{k}_{2}$ seja igual a $\mathrm{k}_{1}$ multiplicado pela concentração de sulfato $\left(\mathrm{C}_{\mathrm{SO}_{4}^{2}}^{-}\right)$, nesta condição. Para concentraçôes de sulfato maiores do que $330 \mathrm{mg}^{-1}{ }^{-1}$, a atividade sulfetogênica foi o processo metabólico predominante. Por outro lado, outros processos metabólicos, que não a redução do sulfato, foram responsáveis pela remoção da matéria orgânica quando as concentraçôes de sulfato forem inferiores $330 \mathrm{mg} . \mathrm{l}^{-1}$. Deste modo, os dados cinéticos sugeriram que o metabolismo variou ao longo do reator, acompanhando o decréscimo na concentração de sulfato. Esta conclusão corrobora com observações microscópicas de morfologias semelhantes a arquéias metanogênicas como sendo mais freqüentes no trecho final do leito do reator.

A remoção, quase que total, de benzeno foi observada sempre antes do ponto de amostragem C/D 8 em todas as fases operacionais. Como os valores de $\mathrm{k}_{4}$ foram nulos em todas as fases, é provável que o benzeno tenha sido consumido principalmente por atividade sulfetogênica com taxa máxima de $0,07 \mathrm{mg}_{\text {benzen o }} \cdot \mathrm{mg}^{-1} \mathrm{SSV} \cdot \mathrm{d}^{-1}$. Este valor foi calculado da equação (2) para concentração de benzeno de $10 \mathrm{mg} \cdot \mathrm{l}^{-1}$, concentração de sulfato de $500 \mathrm{mg} \cdot \mathrm{l}^{-1}$, para $\mathrm{k}_{3}$ de $0,021 \mathrm{mg} \cdot \mathrm{l}_{\text {sulfato }}^{-1} \cdot \mathrm{h}^{-1}$ (Tabela 2) e para concentração de SSV de 43,9 g..$^{-1}$, baseado nos dados obtidos com C/D 4 (dados não mostrados).

De Nardi et al (2002) mediram a capacidade do RAHLF em adsorver benzeno. Os autores relataram valor de adsorção de benzeno de 12,81 $( \pm 1,21) \mu \mathrm{mol}$ por grama de biofilme. Adotando-se os valores obtidos por De Nardi et al (2002), no presente trabalho, a capacidade total de adsorção de benzeno pelo sistema sulfetogênico teria sido de, aproximadamente, $300 \mathrm{mg}$ por todo biofilme. Durante todo período experimental foram introduzidos $1612,53 \mathrm{mg}$ de benzeno no reator. Portanto, apesar da adsorção, a biodegradação foi, provavelmente, o principal fenômeno relacionado com a remoção do benzeno.

Exames de microscopia óptica e eletrônica de varredura do biofilme (Figura 6), na fase de enriquecimento e nas fases com benzeno, mostraram morfologias semelhantes ao longo de todo o leito. Foram visualizados filamentos, bacilos, bacilos ovalados, bacilos delgados, bacilos curvos, cocos, cocos fluorescentes, e morfologias semelhantes a Methanosaeta sp. e Methanosarcina sp.. As produçôes de metano, na atmosfera do reator, além da presença das células fluorescentes confirmaram a presença de arquéias metanogênicas.

Comparando os diferentes pontos de amostragem nas diferentes fases de operação do reator, os perfis de DGGE revelaram que a diversidade, de populaçôes de bactérias, foi particularmente menor nos primeiros pontos de amostragem. Os perfis mostraram a predominância no início do reator (C/D 0 e 4) de pelo menos duas população bacterianas na fase 1 (Figura 7). As setas indicam as populações predominantes em cada amostra. Diferentes fontes de carbono como lactato, etanol e benzeno produziram perfis distintos, mas, de qualquer modo, foi observada a mesma tendência de divisão de populações na primeira porção do reator horizontal (Figura 7).

As adições de benzeno nas fases 2 e 3 mostraram perfil de DGGE similar, com poucas populações dominantes, provavelmente, quatro ou menos espécies (Figura 7). Nas fases 3, 4 e 5 foram visualizadas as mesmas duas bandas no ponto de amostragem C/D 4, porém, com intensidade crescente em relação a concentração crescente de benzeno no reator. Sendo assim, os finger-print gerados nos diferentes ensaios sugeriram aumento da competitividade na comunidade microbiana do reator depois da adição de benzeno. Aparentemente, esta competição favoreceu pelo menos duas populaçóes distintas que se destacaram na fase 3,4 e 5 , sugerindo que estas novas populações estiveram relacionadas com a degradação de benzeno.

No trecho final do reator os perfis não mostraram alteração significativa no padrão de bandas. Sendo assim, as concentraçôes residuais de benzeno não exerceram pressão seletiva representativa a ponto de modificar a composição de populações bacterianas no final do leito do reator, em nenhuma das fases operacionais.

A abordagem com primers específicos para BRS (Figura 8) mostrou a mesma tendência observada com os primers utilizados para Domínio Bacteria, ou seja, perfil uniforme. As populações de BRS foram, preferencialmente, selecionadas nas fases 4 e 5 , onde as poucas mudanças, pelo menos de duas novas populaçôes, foram mais facilmente observadas nos pontos de amostragem C/D 0 e 4.

No gel com as amostras para C/D 20 (dados não mostrados) o perfil, praticamente, nada mudou. Portanto, apesar de apresentarem mudanças sutis no perfil de bandas, algumas populações de BRS foram favorecidas a partir da introdução de benzeno no meio de cultura e, sendo assim, é provável que a degradação do benzeno possa, também, estar relacionada com este grupo de microrganismos.

Os perfis de DGGE com primers específicos para Archaea mostraram que este grupo variou geneticamente, nos diferentes tratamentos e ao longo do reator (Figura 9). As análises de DGGE para o Domínio Archaea evidenciaram diferenças no perfil populacional entre os trechos inicial (Figura 9) e final (dados não mostrados) do reator, inclusive nos diferentes ensaios nutricionais. Pelo menos duas novas populaçōes foram selecionadas ao ponto de já serem visualizadas no gel a partir da fase 2 .

Tabela 2 - Parâmetros cinéticos aparentes do processo

\begin{tabular}{|c|c|c|c|c|c|c|}
\hline \multirow{2}{*}{$\begin{array}{l}\text { Concentração de } \\
\text { benzeno afluente } \\
\left(m g . l^{-1}\right)\end{array}$} & \multicolumn{5}{|c|}{ Parâmetros cinéticos aparentes } & \multirow{2}{*}{$\begin{array}{c}\text { Coeficiente de } \\
\text { Correlação } \\
\mathrm{R}^{2}\end{array}$} \\
\hline & $\begin{array}{c}\mathrm{k}_{1} \\
\left(\mathrm{mg} \cdot \mathrm{l}^{-1}{ }_{\text {sulfato }} \cdot \mathrm{h}^{-1}\right)\end{array}$ & $\begin{array}{c}\mathrm{K}_{2} \\
\left(\mathrm{~h}^{-1}\right) \\
\end{array}$ & $\begin{array}{c}\mathrm{k}_{3} \\
\left(\mathrm{mg} \cdot \mathrm{l}^{-1}{ }_{\text {sulfato }} \cdot \mathrm{h}^{-1}\right) \\
\end{array}$ & $\begin{array}{c}\mathrm{k}_{4} \\
(\mathrm{~h}-1)\end{array}$ & $\begin{array}{l}\mathrm{C}_{\mathrm{COD} \_\mathrm{R}} \\
\left(\mathrm{mg} \cdot \mathrm{r}^{-1}\right)\end{array}$ & \\
\hline 2 & 0,004 & 0,95 & 0,003 & 0 & 95 & 0,999 \\
\hline 5 & 0,004 & 1,03 & 0,005 & 0 & 56 & 0,982 \\
\hline 7 & 0,003 & 1,53 & 0,013 & 0 & 126 & 0,994 \\
\hline 10 & 0,006 & 2,11 & 0,021 & 0 & 57 & 0,995 \\
\hline
\end{tabular}


$\mathbf{A}$

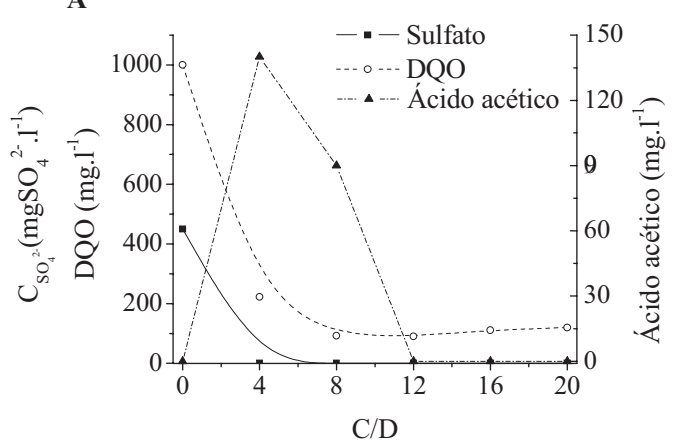

C

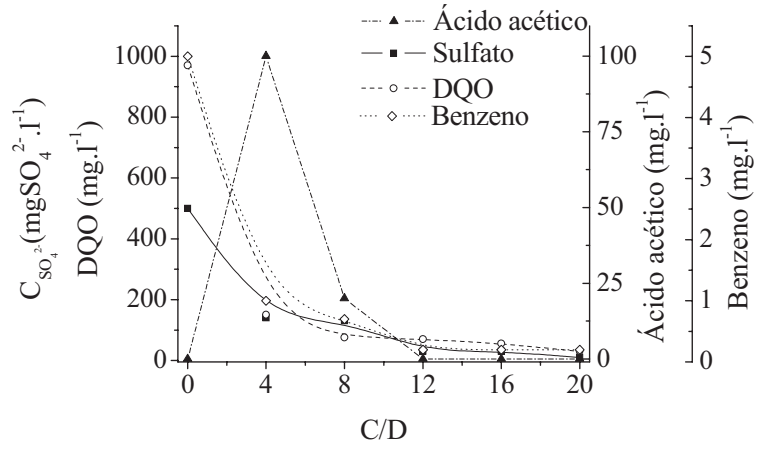

B

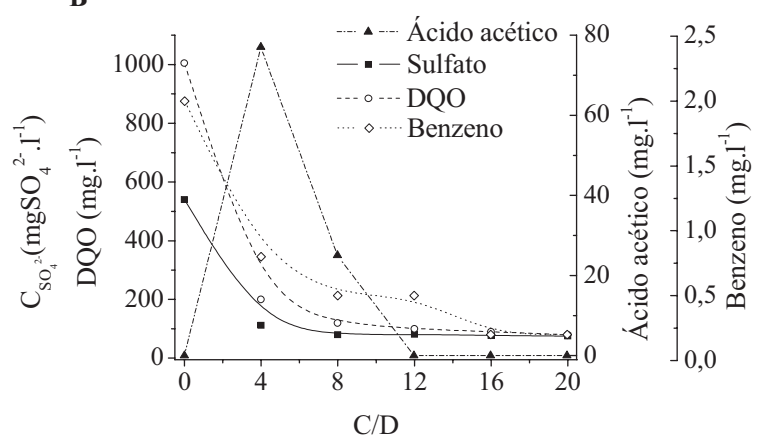

D

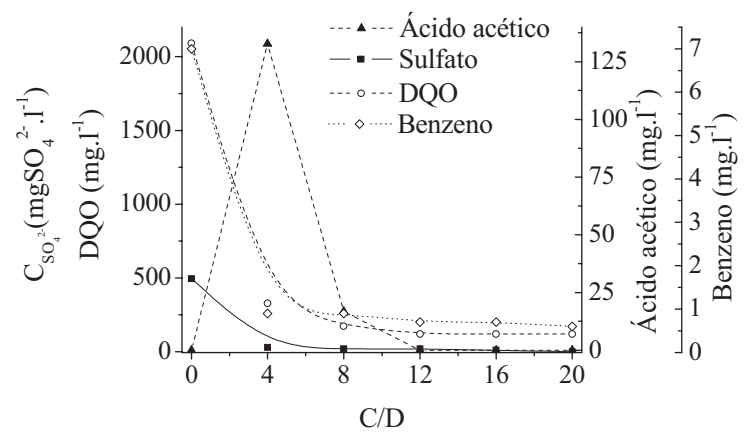

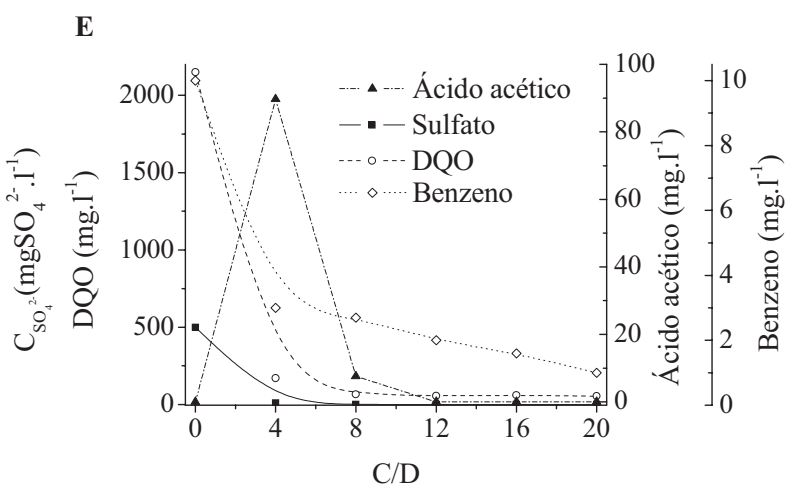

Figura 5 - Variação espacial de sulfato, matéria orgânica (expressa em DQO) e ácido acético na fase I (A), 2 (B), 3 (C), 4 (D) e 5 (E) de operação do RAHLF

Portanto, a variação no perfil das comunidades, em todas as fases, mesmo que sutis, sugeriram que as arquéias sofreram pressão seletiva e, desta forma, poderiam apresentar relação com a degradação de benzeno. Como os processos metanogênicos representam o mecanismo final de degradação da matéria orgânica no ambiente, é pouco provável que as arquéias estejam diretamente ligadas a quebra de anéis aromáticos. Provavelmente, a participação das arquéias deve estar relacionada com a utilização de produtos intermediários, derivados da degradação de etanol e benzeno, no consórcio microbiano.

Finalmente, pode-se concluir que o RAHLF foi eficiente na remoção de etanol e benzeno, na presença de sulfato. A adição de benzeno não interferiu no metabolismo oxidativo do reator, que manteve estabilidade em todas as fases operacionais. As análises de microscopia, óptica e eletrônica de varredura, sugeriram que, tanto, na fase de enriquecimento, com etanol e lactato, quanto, nas fases subseqüentes, com etanol e benzeno, populaçốes de bacilos ovalados e morfologias semelhantes a Methanosaeta sp. foram favorecidas. Ainda, como ácido acético foi o único ácido orgânico detectado, pelas análises cromatográficas, é provável que as BRS não oxidadoras de acetato (oxidadoras incompletas), como, por exemplo, Desulfobulbus propionicus (bacilos ovalados), estiveram presentes de forma significativa no biofilme enriquecido. As análises com gel de DGGE sugeriram que a seletividade do benzeno adicionado ao meio de cultura, tenha favorecido o crescimento de populaçóes 

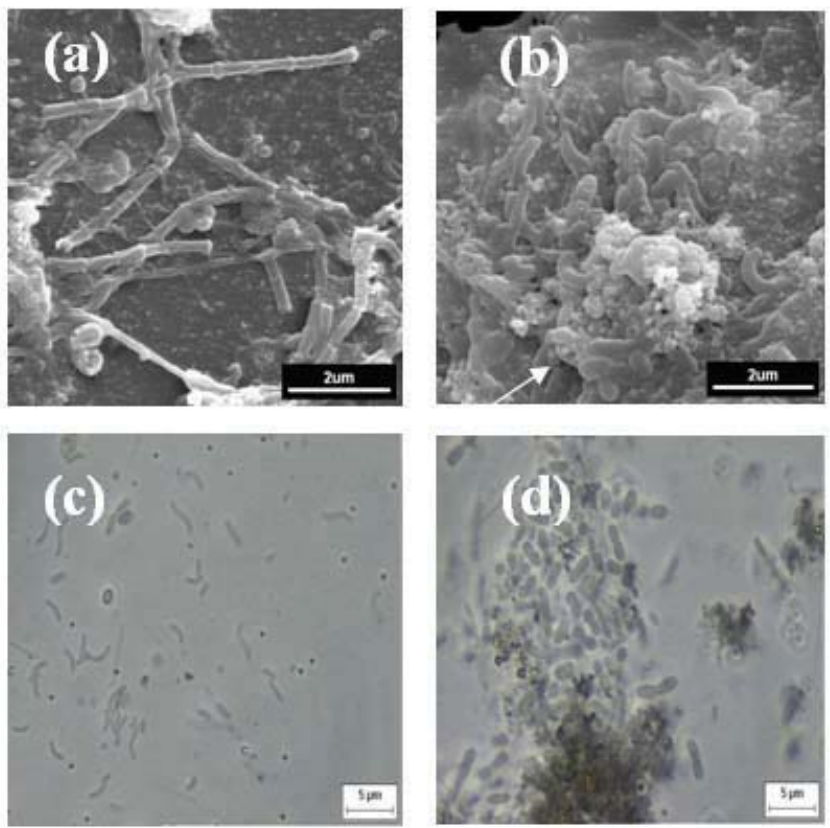

Figura 6 - Microscopias ópticas de contraste de fase e eletrônica de varredura do biofilme do RAHLF na fase 4 (com 7,0 mg.l-1 de benzeno): (a) morfologia semelhante a Methanosaeta sp., (b) bacilos ovalados e bacilos curvos, (c) bacilos curvos, (d) bacilos ovalados

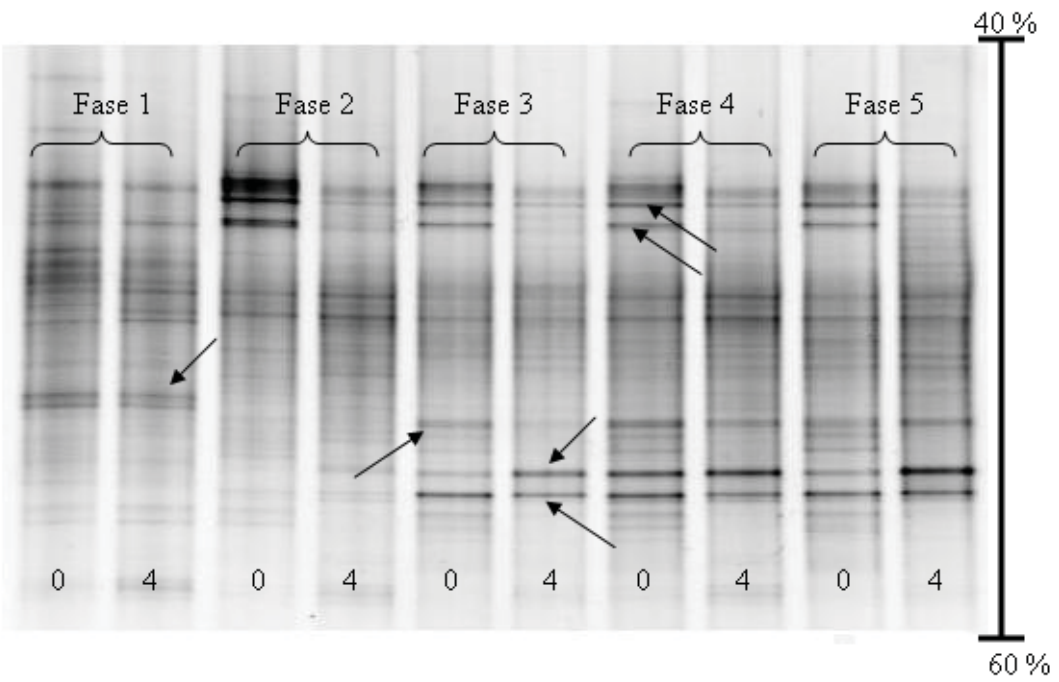

Figura 7 - Gel de DGGE (gradiente de 40-60\%) com amostras de DNA amplificadas com set de primers específico para Domínio Bacteria dos pontos C/D 0 e 4 do RAHLF em todas as fases operacionais de alimentação com benzeno 


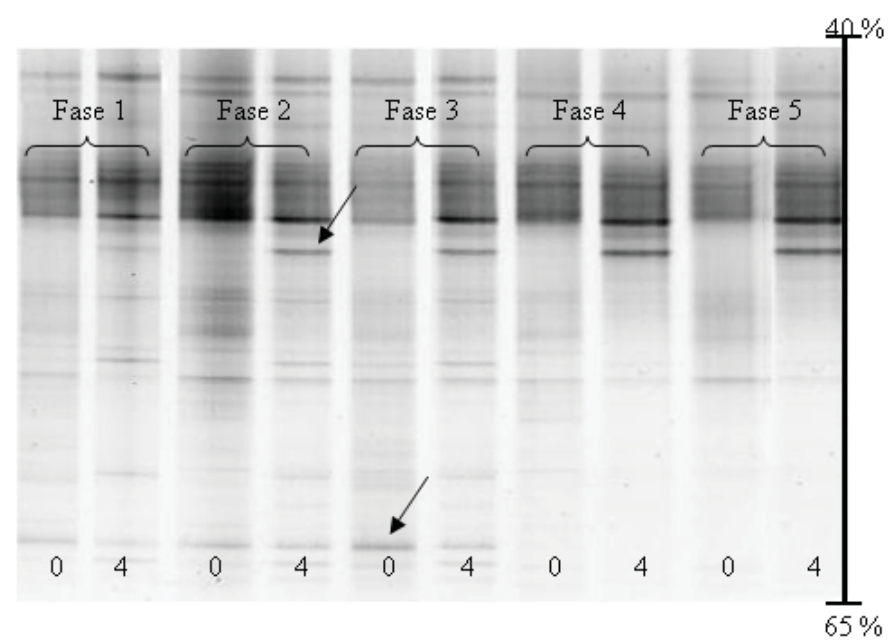

Figura 8 - Gel de DGGE (gradiente de 40-60\%) com amostras de DNA amplificadas com set de primers específico para BRS dos pontos de amostragem C/D 0 e 4 do RAHLF em todas as fases operacionais de alimentação com benzeno
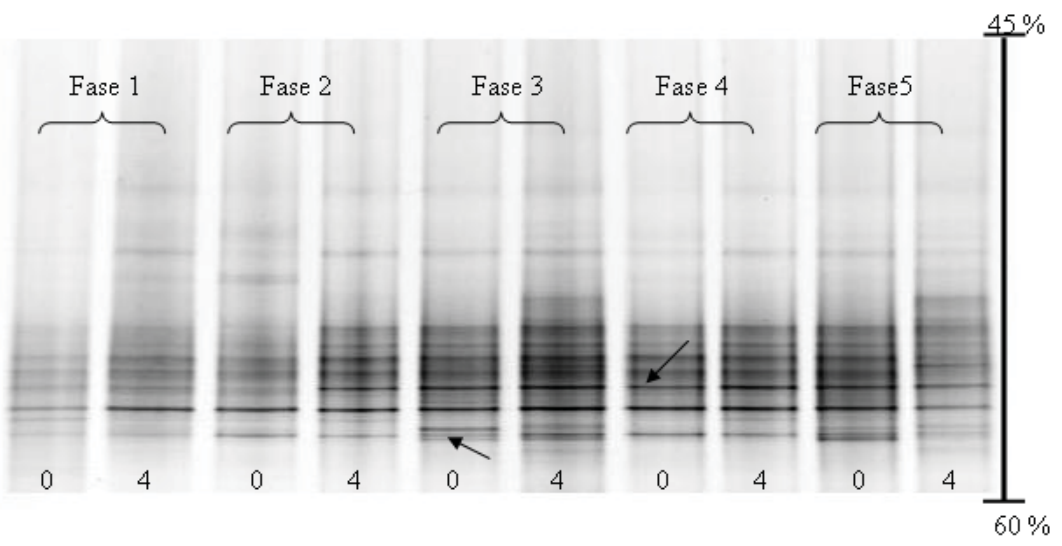

Figura 9 - Gel de DGGE (gradiente de 45-60\%) com amostras de DNA amplificadas com set de primers específico para Domínio Archaea dos pontos de amostragem C/D 0 e 4 do RAHLF em todas as fases operacionais de alimentação com benzeno

que não eram predominantes na biomassa enriquecida. Sugeriram, também, provável relação indireta de arquéias e relação direta de bactérias fermentativas e BRS com a remoção de benzeno.

\section{CONCLUSÕES}

- O RAHLF e as condições adotadas neste experimento foram favoráveis em promover o crescimento microbiano e reduzir sulfato, sob a influência de diferentes concentraçōes de etanol e benzeno;

- Modelos cinéticos de primeira e segunda ordem foram combinados de modo a explicar, satisfatoriamente, as diferentes fases no metabolismo anaeróbio do reator. Segundo este modelo a degradaçãao do benzeno foi alcançada em condiçōes sulfetogênicas, enquanto que, o etanol foi oxidado, tanto, através da redução do sulfato, quanto, através de processos fermentativos e metanogênicos;

- Remoção de etanol e benzeno, na presença de sulfato em RAHLF, foi satisfatória em todas as diferentes concentrações dos mesmos. A adição dos compostos aromáticos não interferiu no metabolismo oxidativo dos reatores, que mantiveram a estabilidade em todas as fases experimentais. As análises dos géis de DGGE sugeriram participação de populaçôes de Bacteria e de BRS para a degradação de benzeno;

- A aplicação do RAHLF em unidades compactas é viável a biorre- mediação de águas contaminadas com etanol e benzeno;

- As concentrações residuais de benzeno no efluente do reator não atenderam aos critérios requeridos pela Resolução CONAMA no 020/86 (0,01 mg. l $^{-1}$ de benzeno) para as classes 1,2 e 3, sendo assim, outro sistema de tratamento deverá ser acoplado para a remoção da concentração residual deste aromático, caso o RAHLF, operado em condiçōes sulfetogênicas, seja adotado para o tratamento in situ de águas contaminadas.

\section{REFERÊNCIAS}

BOOPATHY, R.; KULPA, C.F.; MANNING, J. Anaerobic Biodegradation Of Explosives And Related Compounds By Sulfate-Reducing And Methanogenic Bacteria: A Review. Bioresource Technology 63: 81-89, 1998.

BURLAND, S.M. \& EDWARDS, E.A. Anaerobic Benzene Biodegradation Linked to Nitrate Reduction. Applied and Environmental Microbiology, 65 (2): 529-533, 1999.

CATTONY, E.B.M. et al. Ethanol and toluene removal in a horizontal-flow anaerobic immobilized biomass reactor in the presence of sulfate. Biotechnology and Bioengineering, 91 (2): 244-253, 2005.

CORSEUIL, H. X.; KAIPPER, B. I.; FERNANDES, M. Cosolvency effect in subsurface systems contaminated with petroleum hydrocarbons and ethanol. Water Research 38 (6): 1449-56, 2004.

DA SILVA, M. L. B.; RUIZ-AGUILAR, G. M. L.; ALVAREZ, P. J. J. Enhanced anaerobic biodegradation of BTEX-ethanol mixtures in aquifer columns amended with sulfate, chelated ferric iron or nitrate. Biodegradation 16: 105-114, 2005.

DE NARDI, I. R.; ZAIAT, M.; FORESTI, E. Influence of the tracer characteristics on hydrodynamic models of packed-bed bioreactors. Bioprocess Engineering 21: 469-476, 1999.

DE NARDI, I.R. et al. Anaerobic Degradation of BTEX in a Packed-Bed reactor. Water Science and Technology 45: 175-180, 2002.

DE NARDI, I. R. et al. Anaerobic PackedBed Reactor for Bioremediation of GasolineContaminated Aquifers. Process Biochemistry 40: 587-592, 2005.

DILALLO, R. \& ALBERTSON, O. E. Volatile acids by direct tritation. Journal of Water Pollution C. Fed. 33: 356-365. 1961.

FRANZMANN, P. D. et al. The role of microbial populations in the containment of aromatichydrocarbons in the subsurface. Biodegradation 13:65-78, 2002.

KOLMERT, A.; WIKSTRÖM, P.; HALLBERG, K.B. A Fast And Simple Turbidimetric Method For The Determination Of Sulfate In Sulfate-Reducing Bacterial Cultures. Journal Of Microbiological Methods 41: 179-184, 2000.

KUDO, Y. et al. Methanogen Flora of Paddy Soils in Japan. FEMS Microbiology Ecology 22: 39-48, 1997.

MORAES, E. M. et al. A gas chromatographic determination approach for total volatile acids in effluents of anaerobic reactors treating liquid and 
solid wastes. Proceedings of the VI Latin American Workshop and Symposium on Anaerobic Digestion 2: $235-238,2000$

MUYZER, G. et al. Phylogenetic relationships of Thiomicrospira species and their identification in deep-sea hydrothermal vent samples by denaturing gradient gel electrophoresis of $16 \mathrm{~S} r D N A$ fragments. Archives of Microbiology, 164: 165-72, 1995.

MUYZER, G. et al. Denaturing Gradient Gel Electrophoresis Of Pcr-Amplified 16s rDNA - A New Molecular Approach To Analyze The Genetic Diversity Of Mixed Microbial Communities. Molecular Microbial Ecology Manual 3.4.4.: p. 1-23, 1996

NAKAGAWA, T. et al. Successive changes in community structure of an ethylbenzene-degrading sulphate-reducing consortium. Water Research 36: 2813-2823, 2002.

NATION, J. L. A new method using hexamethyldisilazane for preparation of soft tissues for scanning electron microscopy. Stain Technology 58: 347-351, 1983.

NIELSEN, T. A. et al. Identification of a novel group of bacteria in sludge from a deterioted biological phosphorus removal reactor. Applied Environmental Microbiology 65: 1251-1258, 1999.

RIPLEY, L. E.; BOYLE, W. C.; CONVERSE, J. C. Improved alkalimetric monitoring for anaerobic digestion of high-strength wastes. Journal of Water Pollution C. Fed. 58 (5): 406-465, 1986.

STANDARD METHODS FOR THE EXAMINATION OF WATER AND WASTE WATER. 19th edition. American Public Health Association/ American Water Association/ Water Environment Federation, Washington, DC, USA, 1995.

TOUZEL, J.P. \& ALBAGNAC, G. Isolation and characterization of Methanococcus mazei strain MC3. FEMS Microbiology Letters, 16: 241-245, 1983.

ZAIAT, M. Desenvolvimento do reator anaeróbio horizontal de leito fixo (RAHLF) para tratamento de águas residuárias. Tese de Doutorado, EESCUSP. 156p., 1996.

ZINDER, S.H. et al. Methanogenesis in a thermophilic $\left(58^{\circ} \mathrm{C}\right)$ anaerobic digestor. Methanothrix sp. As an important acetoclastic methanogen. Applied And Environmental Microbiology 47: 796-807, 1984.

WIDDEL, F. \& BAK, F. Gram-Negative Mesophilic Sulfate-Reducing Bacteria. Capítulo 183, The prokaryotes - Second Edition. Springer-Verlag New York Inc., 1992.

Endereço para correspondência:

Eduardo Bosco Mattos Cattony

Centro Federal de Educação

Tecnológica do Ceará

Gerência da Construção Civil

LABIOSAN - Laboratório de

Bioremediação e Saneamento

Av. Treze de Maio, 208 I - Benfica

60040-53I Fortaleza - CE - Brasil

Tel: (85) 3307-3720

Email: ebmcattony@gmail.com 